\title{
DOE/ER/61366-F
}

DOE/ER/61366--TI

Summary of ETL Accomplishments Under

Interagency Agreement \# DE-AI02-92ER61366

Project Title: Shipboard measurements of the cloud-capped marine boundary layer during FIRE/ASTEX

\section{Main Results:}

1. A method was developed from the ASTEX dataset for measuring profiles of liquid water content, droplet size and concentration from cloud radar/microwave radiometer data in marine boundary layer clouds.

2. Profiles of liquid water content, droplet sizes and concentrations were also determined from the first three moments of the Doppler spectrum measured in drizzle with the ETL cloud radar during ASTEX.

3. Turbulence profiles were computed from the ETL cloud radar data taken during ASTEX. These profiles showed diurnal variations caused by enhanced radiational cooling of cloud top at night and by solar warming of cloud interior during the day.

4. Long-lasting "microcells" were discovered from Porto Santo Island by the ETL scanning cloud Doppler radar during ASTEX. These cells were observed to generate a large-area clouds, typically a few hundred square kilometers, from relatively small updrafts of 2 or $3 \mathrm{~m} / \mathrm{s}$ in magnitude and having an area two or three orders of magnitude smaller than that of the resulting cloud. This may be an important cloud-forcing mechanism that has gone unnoticed until now.

5. An analysis of cloud boundary statistics was performed for ASTEX marine boundary layer clouds showing the predominance of clouds having the smallest geometrical thicknesses (s $1 \mathrm{~km}$ ).

6. An integrated ship-mountable system for measuring nearsurface and boundary-layer atmospheric properties was successfully deployed on the R/V Malcolm Baldrige during ASTEX. The system includes tower-mounted micrometeorological sensors for direct covariance flux measurements and a variety of remote sensors for profiling winds, temperature, moisture, and turbulence. A file containing the $\mathrm{R} / \mathrm{V}$ Malcolm Baldrige data set is availabie from the appropriate NASA archive (FairaIl and White, 1994).

7. The time series of cloud bases recorded by laser ceilometers deployed on the R/V Malcolm Baldrige and on Porto Santo Island were analyzed to give statistical information on the distribution of clouds observed during ASTEX. The ASTEX results were compared to the results obtained from four other field programs: FIRE, TIWE, COARE, and SCOPE. Diurnally averaged statistics of cloud fraction helped demonstrate how differently the tropical and 


\section{DISCLAMIER}

Portions of this document may be illegible in electronic image products. Images are produced from the best available original document. 


\section{DISCLAIMER}

This report was prepared as an account of work sponsored by an agency of the United States Government. Neither the United States Government nor any agency thereof, nor any of their employees, make any warranty, express or implied, or assumes any legal liability or responsibility for the accuracy, completeness, or usefulness of any information, apparatus, product, or process disclosed, or represents that its use would not infringe privately owned rights. Reference herein to any specific commercial product, process, or service by trade name, trademark, manufacturer, or otherwise does not necessarily constitute or imply its endorsement, recommendation, or favoring by the United States Government or any agency thereof. The views and opinions of authors expressed herein do not necessarily state or reflect those of the United States Government or any agency thereof. 
mid-latitude marine boundary layers react to solar radiation. The diurnal cycles in cloud fraction observed during FIRE, ASTEX, and SCOPE behaved similarly and were consistent with the idea that shortwave heating contributes to boundary layer decoupling (White et al., 1995a).

8. A new technique for estimating cloud top that uses the $C_{n}^{2}$ profiles measured by the NOAA $915-\mathrm{MHz}$ boundary layer radar/wind profiler was applied to the R/V Malcolm Baldrige data set. The time series of radar/ceilometer-deduced cloud depths correlated well with the time series of liquid water paths measured by the NOAA microwave radiometer (White et al., 1995a).

9. Surface-based measurements of the solar transmission coefficient were used in conjunction with a plane-parallel radiative transfer model to infer values of cloud albedo and cloud optical depth. Corrections were made for the effects of fractional cloud cover and the solar zenith angle dependence of cloud fraction. The relationship between cloud optical depth and liquid water path obtained for the $R / V$ Malcolm Baldrige and Porto Santo Island data sets suggested that the ASTEX clouds formed in significantly cleaner air masses on average than the FIRE clouds. The observed difference can be explained by a factor of two change in the effective radius or a factor of eight change in the cloud droplet number concentration. Independent droplet-size information deduced from $8-\mathrm{mm}$ radar and satellite observations also suggested that the ASTEX cloud droplets were on average a factor-of-two larger than the FIRE cloud droplets (White et al., 1995a).

10. Ship-based measurements of boundary layer aerosol concentration were used to help explain some of the variability observed in the optical properties of the ASTEX clouds. A factor-of-two change in the cloud optical depth versus liquid water path relationship corresponded to a factor-of-eight variation in the observed aerosol concentration, a direct demonstration of the so-called Twomey effect (White et al., 1995a).

11. A collection of recent and ongoing research at NOAA/ETL related to radar measurements of turbulence and microphysical parameters in marine boundary layer clouds was assembled. The techniques use radar reflectivity and other elements of the Doppler velocity spectra collected by radars ranging in frequency from $404 \mathrm{MHz}$ to $34.6 \mathrm{GHz}$. Radar returns dominated by Bragg scatter were used to generate profiles of velocity and refractive index structure function parameters, as well as profiles of vertical velocity variance and skewness. Radar returns dominated by Raleigh scatter provided quantitative information on the size distribution and number concentration of cloud particles as well as the fall velocities, size distribution and number concentration of precipitation particles (White et al., 1995b).

12. Continuous observations of precipitable water vapor, 
integrated cloud liquid, and infrared cloud brightness temperature on board $\mathrm{R} / \mathrm{V}$ Malcolm Baldrige were conducted for the month of June, 1992 during ASTEX.

13. Continuous observations of precipitable water vapor, integrated cloud liquid, infrared cloud brightness, and shortand long-wave radiation were performed on Porto Santo Island during June, 1992 at ASTEX.

14. Statistical analyses of radiometric vapor and liquid measurements from M. Baldrige and Porto Santo Island were completed and results were presented at DOE Science Team Meeting, Feb. 1994, Charleston, S. C.

15. An analysis was completed results were published in JAS (Special Issue on ASTEX) on use of surface-based measurements of short-wave solar flux and radiometric measurements of cloud liquid to derive macrophysical and microphysical properties of marine clouds from observations made from $\mathrm{R} / \mathrm{V}$ Baldrige and on Porto Santo Island.

16. Analysis of "forward" radiative transfer problem at microwave frequencies was completed and results of observations from ASTEX, FIRE II, and PROBE (Kavieng, PNG) were published with the goal of improving the accuracy of radiometric sensing of water substance in the atmosphere.

17) Over the past three years, in collaboration with W.R. Cotton at CSU, a large eddy simulation model of the marine boundary layer was developed and coupled with a model which explicitiy resolves the droplet and aerosol size distributions. The model has been applied to both non-drizzling and drizzling case studies from the ASTEX experiment. Model runs have been performed for a both Porto Santo and $R / V$ Malcolm Baldridge soundings, with an emphasis on the June 16, 1992 case. Measurements obtained with NOAA/ETL and CSU remote sensors ( $\mathrm{K}$-band radar, radiometer, ceilometer and wind-profiler) operating from Porto santo have been used to evaluate the model's performance. The model output has been used to evaluate remote-sensing techniques (Frisch et al., 1995) for measuring cloud LWC and drizzle parameters. The model has recently been upgraded to include an option for keeping track of aerosol dissolved within droplets (solute), and provides a framework for further experiments including aqueous chemistry. (This work is a collaborative effort with $\mathrm{S}$. Kreidenweis at Colorado State University.)

18) A study of the drop recirculation problem and its impact on drizzle production has been completed.

19) A.II of the above results have been published in the open literature, and presented at DOE/ARM Science Team Meetings and at various national and international conferences. A list of the articles resulting from this grant are listed below. 
20. A compact, high prf, $\mathrm{CO}_{2}$ Doppler lidar was deployed on Porto Santo for the first time during ASTEX. Data were gathered in one of two modes: vertically pointing or velocity-azimuth-disply (VAD) scans at 37 and 51 degree elevation angles. Primary objective of the lidar deployment was to supplement cloud radar observations of vertical motion and momentum flux with similar measurements in the subcloud boundary layer. A significant post analysis effort has centered on correcting the effects of a non-uniform receiver spectrum response that was discovered in the data. This effort has been successful, and scientific analysis of the data is ongoing. Comparisons of lidar and radar vertical motion fields show good

agreement.

21. Operational problems and performance of $\mathrm{CO}_{2}$ lidar in a marine environment were evaluated during ASTEx. Although the marine boundary layer is generally a favorable lidar environment, due to the surplus of large particles, we found that the corrosive nature of the sea salt caused significant damage to the scanner mirror. The full impact of the marine environment is being assessed, and will be considered for operation of a Doppler lidar from a ship as part of a DOE-sponsored observational campaign scheduled for March, 1996.

\section{Acronyms :}

FIRE - First International satellite Cloud Climatology Program Regional Experiment (marine stratocumulus phase) ASTEX - Atlantic Stratocumulus Transition Experiment COARE - Coupled Ocean Atmosphere Response Experiment TIWE - Tropical Instability Wave Experiment SCOPE - San Clemente Ocean Probing Experiment

\section{Publications:}

Albrecht, B.A.,C.S. Bretherton, D. Johnson, W.H. Schubert, A.S. Frisch, 1995. The Atlantic Stratocumulus Transition Experiment -- ASTEX, accepted by Bull Amer. Meteor Soc..

Cahalan, R., W.Ridgway, W. Wiscomb, T. Bell and J.Snider, 1994. The Albedo of Fractal stratocumulus Clouds, J.Atmos. SCi., 51, 2434-2455.

Cahalan,R. F., D. Silberstein, and J. B. Snider, 1994. Liquid water path and plane-parallel albedo bias during ASTEX, J.Atmos. Sci., Special Issue on ASTEX, in press.

Cahalan, R., W. Ridgway, W. Wiscomb, T. Bell and J.Snider, 1994. The Albedo of Fractal Stratocumulus Clouds, I.Atmos. Sci., $51,2434-2455$.

Cahalain, R. F., D. Silberstein, and J. B. Snider, 1994. Liquid water path and plane-parallel albedo bias during ASTEX, J. Atmos. Sci., Special Issue on ASTEX, in press. 
Cotton,W.R., B.B. Stevens, G. Feingold, and R.L. Walko, 1993. Large eddy simulation of marine stratocumulus cloud with explicit microphysics. ECMWF/GCSS Workshop on parameterization of the Cloud Topped Boundary Layer, ECMWF, Reading, United Kingdom, June 8-11, 1993.

Eberhard,W.L., 1993. Co Iidar technique for observing characteristic drop size in water clouds. IEE Transactions on Geoscience and Remote Sensing, 31, 56-63.

Fairall,C.W., and A. B. White, 1995. A ship-based system for direct surface flux and remote boundary-layer measurements over the ocean. In The Air-Sea Interface, M. A. Donelan, W. H. Hui, and W. J. Plant, eds., The University of Toronto Pres, Toronto, to appear.

Feingold,G., A.S. Frisch, B. Stevens and W.R. Cotton, 1995. A modelling and observational study of ASTEX marine stratocumulus clouds. AMS Conference on Cloud Physics, Dallas, January 15-20, 1995.

Feingold, G.,B. Stevens, W.R. Cotton, and R.L. Walko, 1994. An explicit microphysics/LES model designed to simulate the Twomey Effect. Atmospheric Research, 33, 207-233.

Feingold,G., A.S. Frisch, B.stevens and W.R. Cotton, 1994. Radar/radiometer retrievals of cloud liquid water and drizzle: analysis using data from a 3-D LES simulation of marine stratocumulus clouds. DOE Science Team Meeting, Charlotte NC, March 1994.

Feingold,G.,A.S. Frisch, B. Stevens and W.R. Cotton, 1994. Evaluation of remote sensing techniques for measuring cloud water and drizzle in marine stratocumulus clouds. 2nd Intnl. Conf. Meteor. Oceanography of the Coastal Zone, Lisbon, Portugal, sept. 22-27.

Feingold,G.,A.S. Frisch, B. Stevens and W.R. Cotton, 1994. Simulations of marine stratocumulus clouds during ASTEX: Comparisons with radar/radiometer measurements. 2nd Intnl. Conf. Meteor. Oceanography of the Coastal Zone, Lisbon, Portugal, sept. 22-27.

Feingold, G.,B. Stevens, W.R. Cotton, and A. S. Frisch, 1995. Production of drizzle in stratocumulus in the context of Bowen's model. Submitted, J.Atmos. Sci., April, 1995.

Frisch,A.S. and C.W. Fairall, 1993. Ka-band Doppler radar measurements of drizzle parameters. 26th Internationale AMS.

Frisch,A.S.,D.H. Lenschow, C.W. Fairall, W.H. Schubert, and J.S. Gibson. 1995. Doppler Radar Measurements of Turbulence in Marine Stratiform Cloud During ASTEX, accepted by J. Atmos.Sci. 
Frisch,A.S., C.W. Fairall and J.B. Snider, 1995. On the Measurement of Stratus Cloud and Drizzle Parameters in ASTEX with a $k_{\alpha}$-Band Doppler Radar and a Microwave Radiometer, accepted by J.Atmos. Sci.

Frisch,A.S.,C. W. Fairall, and J. B. Snider, 1994. Use of a cloud-sensing radar and a microwave radiometer as a stratus cloud profiler, Proceedings SPIE, Vol. 2222, The International Society for Optical Engineering, 5-7

Gibson,J.S.,A.S. Frisch and D.J. Lenschow. Ka-band measurements of vertical velocity variance and skewness in marine stratus clouds. 26th International Conference on Radar Meteorology, 492-494, May 24-28, 1993, Norman, OK, AMS.

Gollmer, S.M.,R.F. Cahalan and J.B. Snider, 1994. Modeling of Integrated Iiquid Water Inhomogeneity in Marine Stratocumulus, Preprint Volume, 8th Conf. on Atmospheric Radiation, Nashville, TN, Jan. 23-28, 1994, AMS, 496-498.

Gollmer, S.M.,R. F. Cahalan, and J. B. Snider, 1994. Windowed and wavelet analysis of marine stratocumulus cloud inhomogeneity", J.Atmos. Sci. Special Issue on FIRE Results, in press. April, Orlando, Florida, 238-249.

Gollmer, S.M. , Harshvardhan, Robert F. Cahalan, and Jack B. Snider, 1995. Windowed and wavelet analysis of marine stratocumulus cloud inhomogeneity, J.Atmos.Sci., Special Issue on FIRE II, in press.

Gollmer,S.M.,R.F. Cahalan and J.B. Snider, 1994. Windowed and wavelet analysis of marine stratocumulus cloud inhomogeneity, J.Atmos. Sci. Special Issue on FIRE Results, in press.

Han, Y.,J.B. Snider, E.R. Westwater, S.H. Melfi and R.A. Ferrare, 1994. Observations of Water Vapor by Ground-Based Microwave Radiometers and Raman Lidar, I. Geophys. Res. 99 D9, 18695-18702.

Intrieri,J.M.,G.L. Stephens, W.L. Eberhard and T. Uttal, 1993. A method for determining cirrus cloud particle sizes using lidar and radar backscatter technique. Journal of Applied Meteorology, $32,6,1074-1882$.

Kropfli,R.A. and B.W. Orr. Observations of microells in the marine boundary layer with $8-\mathrm{mm}$ wavelength Doppler radar. 26th International Conference on Radar Meteorology, 605-606, May 24-28, 1993, Norman, OK, AMS.

Kropfli,R.A.,S.Y. Matrosov,T. Uttal,B. W. Orr, A.S. Frisch, K. A. Clark, B. W. Bartram, R. F. Reinking, J. B. Snider, and B. E. Martner, 1995. Cloud physics studies with $8 \mathrm{~mm}$ wavelength radar, Atmospheric Research, 35, 299-313. 
Kropfli,R.A. and R.D. Kelly, 1995. Meteorological Research Applications of MM-Wave Radar. Accepted for publication in Meteorology and Atmospheric Physics.

Kropfli,R.A. and B.W. Orr, 1993. Observations of Microcells in the Marine Boundary Layer with 8-mm Wavelength Doppler Radar, Proc. 26th International Conference on Radar Meteorology. AMS, Boston, 492-494.

Kropfli,R.A.,S.Y. Matrosov, T. Uttal, A. S. Frisch, and J. B. Snider,1994. Studies of Radiatively-important Clouds with 8-Millimeter Wavelength Doppler Radar, Proc. IGARSS 94.

Matrosov, S.Y.,R.A. Kropfli, and J.B. Snider, 1995. Some results of ice cloud microphysics retrieval during the FIRE II and ASTEX Experiments, Proc. International Union of Geodesy and Geophysics (IUGG) XXI General Assembly, Boulder, CO, July 1-14.

Palmer,A.J., 1995. Nonlinear Dynamical Analysis of Turbulence in a Stable Cloud Layer, Chaos V5, 1.

Palmer,A.J,A.S Frisch and Graham Feingold, 1993. Dynamical attractor reconstruction for a marine stratocumulus cloud. Proc. 2nd Experimental Chaos conference, Washington, DC, Oct. 6-8, 1993, ONR.

Reagan,J.,K. Thome,B. Herman, R. Stone,J. DeLuisi and J.Snider, 1994. A comparison of columnar water vapor retrievals obtained with near-IR solar radiometer and microwave radiometer measurements, I. Appl. Meteorol., in press.

Snider,J.B., 1994. Observed and Theoretical Atmospheric Emission at 20, 30 and $90 \mathrm{GHz}$ : Recent Results from Land and Ocean-Based Locations, Proc. Specialists Meeting on Micro wave Radiometry and Remote sensing Applications, February 11-17, 1994, Rome Italy, D. Solimini, Ed., VSP Press, Utrecht, in press.

Snider,J.B.,D.A. Hazen, A. J. Francavilla, W. B. Madsen, and M. D. Jacobson, 1995. Comparison of observed and theoretical millimeter wave emission: implications for remote sensing of atmospheric water, Proc. IGARSS'95, Firenze, Italy, July 10-14, submitted to ETL review March 30, 1995.

Snider,J.B., 1994. Observed and Theoretical Atmospheric Emission at 20,30 and $90 \mathrm{Ghz}$. Recent Results from Landand Ocean-Based Locations, Proc. Specialists Meeting on Microwave Radiometry and Remote sensing Applications, February 11-17,94, Rome Italy, D. Solimini, Ed., VSP Press, Utrecht, reviewed article in press.

Snider,J.B.,D. A. Hazen, A. J. Francavilla, W. B. Madsen, and 
M.D. Jacobson, 1994. Ground-based radiometric observations of atmospheric water for climate research, Proc. ARM Science Team Meeting, Charleston, S. C., Feb. 28 to March 3 .

Stevens, B., G. Feingold, W.R. Cotton and R.L.Walko, 1995. On elements of the microphysical structure of numerically simulated stratocumulus. Submitted, I. Atmos.Sci., April, 1995.3.

Stevens, B.,W. R. Cotton, G. Feingold and R.L. Walko, 1994. Large eddy simulation of marine stratocumulus cloud with explicit microphysics. American Meteorological Society, Radiation Conference, Nashville, Jan. 1994

Stevens,B.,G. Feingold, W.R. Cotton and R.L. Walko, 1995. on elements of the microphysical structure of numerically simulated stratocumulus. Submitted, I. Atmos..Ocean Tech, submitted.

Uttal,T.,S. Matrosov, S. Frisch, J. Intrieri, J. Snider, R. Kropfli, and C. Fairall, 1994. Remotely sensed profiles of ice water content, liquid water content, particle sizes, concentrations, vertical velocities, and cloud boundaries: Project Statistics for FIRE II and ASTEX, Proc. Conf. on Tropospheric Profiling, Hamburg, Germany, Aug. 30 to Sept. $2,1994$.

Uttal, T. and A.S. Frisch, 1994. Cloud boundaries during ASTEX. Proc. 8th Annual Conference on Atmospheric Radiation, Nashville, TN, January 23-28, 1994, AMS, Proc.-261.

White,A.B.,C.W. Fairal1, A. S. Frisch, B.W. Orr, and J.B. Snider, 1995. Radar Measurements of Turbulence and Microphysics in Clouds, submitted to Atmos Res.

White,A.B.,C.W. Fairall, and Jack B. Snider, 1994. Surface-based remote sensing of marine boundary-layer cloud properties, I. Atmos. Sci., Special Issue on FIRE Results, in press.

White,A.B.,C. W. Fairall, A. S. Frisch, B. W. Orr, and J. B. Snider, 1995b. Recent radar measurements of turbulence and microphysical parameters in marine boundary layer clouds, Atmos. Res., in press. 